\title{
Progressive Development of the Osteoblast Phenotype during Differentiation of Osteoprogenitor Cells Derived from Fetal Rat Calvaria: Model for in Vitro Bone Formation
}

\author{
Noriko Yamamoto, Kazuyuki FuruYa, and Keigo HanadA* \\ Drug Discovery Research Department, Central Research Laboratories, Kaken Pharmaceutical Co., Ltd., 14 Shinomiya \\ Minami Kawara-cho, Yamashina-ku, Kyoto 607-8042, Japan. Received November 13, 2001; accepted January 17, 2002
}

\begin{abstract}
Osteoblasts are the primary cells responsible for bone formation and are thought to originate from mesenchymal osteoprogenitor cells within skeletal tissues. To elucidate the osteoblastic differentiation process, fetal rat calvariae (FRC) were enzymatically digested and fractionated to provide an osteoprogenitor-enriched cell population. The third fraction of cells from the five sequential digestions tested showed a significant osteogenic response to dexamethasone (Dex), a well-known differentiation hormone, which was demonstrated by high alkaline phosphatase activity early in culture and enhanced calcium deposition and bone nodule formation in late stage cultures. These data indicate that fraction three contains a large number of osteoprogenitor cells. During the osteoblastic differentiation of the third fraction of FRC cells, the formation of collagen cross-links (pyridinoline and deoxypyridinoline) was time-dependently accelerated with the accumulation of collagens, which coincided with an onset of mineralization of the cultures, i.e., calcium deposition and bone nodule formation. Moreover, noncollagenous matrix proteins, bone sialoprotein and osteocalcin, were also increased at both mRNA and protein level in Dex-treated cultures with advancing culture periods. Further examination for mRNA expression of bone morphogenetic proteins (BMPs) and TGF- $\beta 1$ revealed a notable elevation in BMP-6 mRNA expression on days 3 and 10, and no significant change in TGF- $\beta 1$ expression. These observations suggested that the progressive formation of collagen cross-links, production of noncollagenous proteins, and up regulation of BMP-6 mRNA play an important role in the osteoblastic differentiation process of osteoprogenitor cells isolated from FRC. This culture system provides us a suitable model for in vitro bone formation.
\end{abstract} BMP-6

Key words fetal rat calvaria; osteoprogenitor cell; osteoblastic differentiation; collagen cross-link; noncollagenous protein;

Bone consists of various types of cells and an abundant mineralized extracellular matrix. Bone formation as well as bone resorption are essential processes for the maintenance of normal bone structure and calcium homeostasis in the body. In addition to its physiological role, bone formation plays important roles in pathological disorders such as osteoporosis, metabolic bone diseases and bone fracture. Osteoblasts are the primary cells responsible for bone formation, and are believed to originate form mesenchymal osteoprogenitor cells within skeletal tissues. ${ }^{1,2}$ Therefore, the elucidation of the function and differentiation process of the osteoprogenitor cells will allow us to understand a major portion of the process of bone metabolism.

Many model systems have been used to examine bone cell metabolism; these include cultures of calvariae and long bone explants, continuously cultured osteosarcoma cell lines, as well as primary cultures of osteoblastic cells. ${ }^{3,4)}$ Each model system offers unique advantages to increase our understanding of bone development and metabolism. Of these, clonal osteosarcoma cell lines are thought to be useful tools because of their relatively homogeneous population of osteoblastic cells. However, since osteosarcoma cell lines express intrinsic properties reflecting specific stages of osteoblast differentiation, only a limited number of cell lines retain the capacity to form mineralized bones in vitro, reflecting terminal differentiation of osteoblasts. Another useful culture system is primary osteoblastic cells isolated from bones by enzymatic digestion, which have various phenotypic characteristics of osteoblasts including the potential to form mineralized bones in vitro. However, the spatial and temporal expression patterns of osteoblast phenotypes in this system have not been fully understood, since primary cultures of osteobastic cells consist of a heterogeneous cell population and these cultures often lose bone formation ability after several passages of cells. ${ }^{5,6}$ )

Osteoblast precursor cells isolated by the enzymatic digestion of fetal rat calvaria (FRC) can be grown in culture to develop into mature osteoblasts which form mineralized bone nodules. ${ }^{6-8)}$ This process can be accelerated by a treatment with glucocorticoid hormones such as dexamethasone (Dex). Dex-stimulated cultures of FRC cells have been extensively characterized and have been shown to produce high levels of alkaline phosphatase (ALP), type I collagen, osteonectin, osteocalcin, and other noncollagenous proteins that are found in bone. In addition, these proteins are expressed in a temporal pattern similar to what is seen in vivo. ${ }^{6,8-11)}$ Nevertheless, it is still unknown which fraction of cells obtained from sequential digestions of FRC exhibits unique osteoblastic phenotypes and is suitable for analyses of phenotypic changes in cultures during the differentiation process, since pooled fractions of FRC cells have been frequently used.

In the present study, we fractionated FRC cells by sequential enzymatic digestions and characterized the osteoblastic differentiation ability of each fraction of cells. Thereafter, using a rich fraction of osteoprogenitor cells, the production of bone matrix proteins, matrix maturation manifested by cross-linking, and gene expression were investigated for analyses of changes in osteoblastic phenotype. In addition, time-dependent changes in the gene expression of osteoblast differentiation factors, BMPs (bone morphogenetic proteins) and TGF- $\beta 1$, were examined during the differentiation of FRC cells in vitro. 


\section{MATERIALS AND METHODS}

Culture of FRC Cells Calvariae were dissected aseptically from 20-day fetuses of timed-pregnant Sprague-Dawley (SD) rats (Japan SLC, Hamamatsu). Frontal and parietal bones were cleaned of loose soft connective tissue and submerged in alpha modification of Eagle's medium ( $\alpha$-MEM) (ICN, Irvine, CA, U.S.A.). Calvariae were digested at $37^{\circ} \mathrm{C}$ for $20 \mathrm{~min}$ with shaking of an enzymatic solution containing $0.1 \%$ collagenase (Wako Pure Chemical Industries, Ltd., Osaka, Japan) and $0.05 \%$ trypsin containing $0.53 \mathrm{~mm}$ EDTA (Gibco BRL, Gaithersburg, MD, U.S.A.) in $\alpha$-MEM. This procedure was repeated to yield a total of five digests. The cells were collected by centrifugation at $1000 \mathrm{rpm}$ for $5 \mathrm{~min}$. The cells were then resuspended in $\alpha$-MEM containing $10 \%$ FCS and antibiotics (penicillin, $100 \mathrm{unit} / \mathrm{ml}$ and streptomycin, $100 \mu \mathrm{g} / \mathrm{ml}$, all from Gibco BRL). The cells of each fraction were seeded separately in T-75 vented flasks (Becton-Dickinson Labware, Franklin Lakes, NJ, U.S.A.) at $1 \times 10^{6}$ cells/flask. Cells were grown to subconfluence over the next $3-4 \mathrm{~d}$ at $37^{\circ} \mathrm{C}$ in $5 \% \mathrm{CO}_{2}$ with humidification. The cells were trypsinized, counted, and replated in 24-well plates and $60 \mathrm{~mm}$ dishes (all from Becton-Dickinson Labware) at a density of $5 \times 10^{3}$ cells $/ \mathrm{cm}^{2}$. Cells were grown to confluence (Day 0) and the medium was changed to 5\% FCS plus $50 \mu \mathrm{g} / \mathrm{ml}$ of ascorbic acid (Wako Pure Chemical Industries), $10 \mathrm{~mm}$ BGP and $10^{-7}$ M Dex (all from Sigma, St. Louis, MO, U.S.A.) to induce bone formation. During the culture, medium was changed every $3-4 \mathrm{~d}$.

Measurement of ALP Activity ALP activity was determined for FRC cells on days 7 and 14 of triplicate cultures. ${ }^{12)}$ The cells in each well of 24-well culture plates were rinsed once with phosphate buffered saline (PBS). Then $0.3 \mathrm{ml}$ of $1.33 \mathrm{mg} / \mathrm{ml}$ solution of ALP substrate ( $p$-nitrophenyl phosphate from Sigma) in a buffer consisting of $50 \mathrm{~mm}$ Tris- $\mathrm{HCl}$ saline (TBS: pH 9.0) was added per well. After 30 min incubation at $37^{\circ} \mathrm{C}$, the solution was appropriately diluted, and transferred to a 96-well culture plate (Becton-Dickinson Labware) for determination of absorbance at $405 \mathrm{~nm}$ on microplate reader (Multiscan Bichromatic, Labsystems Oy, Helsinki, Finland). A standard curve generated from a series of dilutions of $p$-nitrophenol (Sigma) was used to determine the concentration of the enzyme reaction product.

Bone Nodule Assay For evaluation of activities of osteoprogenitor cells, bone nodule assay was performed because the number of bone nodules was linearly related to the number of cells plated and thus one nodule arose from one osteoprogenitor cell. ${ }^{6,11,13)}$ The presence of mineralized bone nodules in FRC cultures was demonstrated with von Kossa staining. ${ }^{14)}$ On day 14, triplicate cultures of each fraction of FRC cells in 24-well plates were rinsed once with PBS and fixed with $100 \%$ ethanol for $10 \mathrm{~min}$. Freshly prepared $2 \%$ silver nitrate (Sigma) was added to the plates $(0.3 \mathrm{ml} /$ well), which were placed in a dark environment for $12 \mathrm{~min}$. The plates were rinsed twice with distilled water and then exposed to bright light for $15 \mathrm{~min}$. The number and total area of strongly stained nodules in each well were measured by an Olympus SP 1000 Image Analyzer (Osaka, Japan).

Determination of Calcium Contents On days 14 and 21 , triplicate cultures of each fraction of FRC cells in 24-well plates were rinsed once with PBS and fixed with $100 \%$ ethanol for $10 \mathrm{~min}$. After the ethanol was removed, $0.3 \mathrm{ml}$ of $1 \mathrm{~N} \mathrm{HCl}$ was added to each well to decalcify the cultures. ${ }^{14)}$ After $24 \mathrm{~h}$, the $\mathrm{HCl}$ supernatant was recovered, appropriately diluted. The calcium in samples was directly measured at $422.8 \mathrm{~nm}$ on Atomic Absorption Spectrophotometer (Hitachi 170-30, Tokyo, Japan) and its amount was determined from a standard curve.

Quantification of Hydroxyproline The amount of hydroxyproline in the cultures was quantified as an index of collagen production by the method previously described. ${ }^{9,15)}$ Cultured cells grown in $60 \mathrm{~mm}$ dish were harvested on days $0,3,7,10,14$ and 21. After rinsing once with PBS, $1 \mathrm{ml}$ of distilled water was added to the cultures and then the cells were collected to a screw-capped glass tube. They were hydrolyzed in $12 \mathrm{~N} \mathrm{HCl}$ at $110^{\circ} \mathrm{C}$ for $17-18 \mathrm{~h}$ and cooled with running tap water. Then, $0.5 \mathrm{ml}$ of the sample was diluted equally with $0.1 \mathrm{~N} \mathrm{HCl}$ and adjusted to $\mathrm{pH} 9.0-9.5$ with $12 \mathrm{~N}$ and $1 \mathrm{~N} \mathrm{KOH}$. The sample was then carefully diluted to $5 \mathrm{ml}$ with distilled water in the tube and $3.0 \mathrm{~g}$ of $\mathrm{KCl}$ was added to it. Thereafter, $0.5 \mathrm{ml}$ of $1.25 \mathrm{~m} \beta$-alanin (Nacalai Tesque, Kyoto, Japan) and $1 \mathrm{ml}$ of $\mathrm{KBr}(0.2 \mathrm{M}$ boric acid: $0.05 \mathrm{M}$ borax $=4: 6 ; \mathrm{pH} 8.7$ ) were added to the sample, and reacted for $20-30 \mathrm{~min}$ at room temperature. The sample was then oxidized by the addition of exactly $1.0 \mathrm{ml}$ of the $0.2 \mathrm{M}$ chloramine $\mathrm{T}$ methoxyethanol solution, and the tube was allowed to stand at room temperature for $25 \mathrm{~min}$. Three milliliters of $3.6 \mathrm{~m}$ sodium thiosulfate and $5 \mathrm{ml}$ of toluene was added to the tube, which was then vigorously shaken for $5 \mathrm{~min}$, centrifuged at $2000 \mathrm{rpm}$ for $5 \mathrm{~min}$, and placed in boiling water bath for $30 \mathrm{~min}$. The tube was cooled with running tap water, and exactly $5 \mathrm{ml}$ of toluene was added. The tube was shaken for $5 \mathrm{~min}$, and centrifuged at $2000 \mathrm{rpm}$ for $5 \mathrm{~min}$. Exactly $2.5 \mathrm{ml}$ of the toluene extract was placed in a clean glass tube, and $1.0 \mathrm{ml}$ of the Ehrlich's reagent (Nacalai Tesque) was added, and it was allowed to stand at room temperature for $30 \mathrm{~min}$. The absorbance was read at $560 \mathrm{~nm}$ with a model 150-21 Spectrophotometer (Hitachi, Tokyo, Japan) and the amount of hydroxyproline determined from standard curve.

Measurement of Collagen Cross-Links The amount of two forms of collagen cross-links, pyridinoline (Pyr) and deoxypyridinoline (Dpy), was measured by a modification of the method reported before. ${ }^{16)}$ The remaining hydrolized culture samples after determination for hydroxyproline content were used for this assay. To a column packed with $400 \mathrm{ml}$ of 5\% CF1 cellulose (Whatman, Kent, U.K.) slurry in butanolic mobile phase (acetic acid: water: butanol=1:1:4), a mixture of the sample $(0.5 \mathrm{ml})$, glacial acetic acid $(0.5 \mathrm{ml})$, butanol $(2 \mathrm{ml})$ and the CF1 slurry $(0.5 \mathrm{ml})$ was applied. The column was then washed with a total of $15 \mathrm{ml}(3 \times 5 \mathrm{ml})$ of the butanolic mobile phase and the washings discarded. The collagen corss-links were eluted with $5 \mathrm{ml}$ of distilled water and the aqueous fraction together with some residual butanol collected in the tube. After centrifugation at $1000 \mathrm{rpm}$ for $5 \mathrm{~min}$, the lower layer containing the cross-links was carefully removed and freeze-dried. The freeze-dried samples were redisolved in $0.5 \mathrm{ml}$ of the initial mobile phase (solution A: $5 \%$ acetonitrile and $0.1 \%$ heptafluorobutyric acid) and centrifuged at $1000 \mathrm{rpm}$ for $5 \mathrm{~min}$. After the supernatant was filtered $(0.45 \mu \mathrm{m}$ filter, Millipore, Bedford, MA, U.S.A.), aliquots of them were subjected to High Performance Liquid Chromatography (HPLC) to determine the concentration of 
Pyr and Dpy. The HPLC system (Shimadzu, Kyoto, Japan) consists of a SCL-6A system controller, a SPD-7AV UV-VIS spectrophotometric detector and a C-R4A data analyzer, chromatopac. The separation was performed with a linear gradient from 5 to $60 \%$ acetonitrile in $0.1 \%$ heptafluorobutyric acid for $30 \mathrm{~min}$, followed by isocratic elution at $5 \%$ acetonitrile in $0.1 \%$ heptafluorobutyric acid for $10 \mathrm{~min}$ on a Wakosil-II-packed column 5C18-AR $(4.6 \times 150 \mathrm{~mm}$, Wako Pure Chemical Industries). The flow rate was $1.0 \mathrm{ml} / \mathrm{min}$. The retention time and peak height were measured with the chromatopac. The pure standards, Pyr and Dpy (Wako Pure Chemical Industries) were used for the calibration of the column.

Measurement of Osteocalcin Synthesis The amount of osteocalcin secreted into the culture media was determined by enzyme immunoassay using a rat osteocalcin ELISA kit (Amersham Pharmacia Biotech UK Ltd., Buckinghamshire, U.K.). The culture media were harvested $500 \mu$ l when they were freshly changed on days $0,3,7,10$ and 14 , and stored at $-20^{\circ} \mathrm{C}$ until the assay. The amount of osteocalcin accumulated during this period was measured.

RT-PCR Analysis Total RNA was extracted from the cultured cells on days $0,3,7,10$, and 14 with a commercial kit (Qiagen Inc., Chatsworth, CA, U.S.A.) following the manufacturer's instructions. The purity and amount of isolated RNA were assessed by spectrophotometric measurement at 260 and $280 \mathrm{~nm}$. Total RNA $(2.5 \mu \mathrm{g})$ was reverse transcribed to cDNA at $42{ }^{\circ} \mathrm{C}$ for $50 \mathrm{~min}$ in a volume of $20 \mu \mathrm{l}$ containing the following reagents: $0.5 \mathrm{~mm}$ dNTP mix; $10 \mathrm{~mm}$ dithiothreitol (DTT); $0.5 \mu \mathrm{g}$ Oligo(dT) ${ }_{12-18} ; 1 \times$ first strand buffer $\left(5 \times=250 \mathrm{~mm}\right.$ Tris, $375 \mathrm{~mm} \mathrm{KCl}$ and $15 \mathrm{~mm} \mathrm{MgCl}_{2}$, $\mathrm{pH}$ 8.3) and $20 \mathrm{U}$ of Superscript II (RNase H-free reverse transcriptase) (all from Gibco BRL). After terminating the reaction at $70^{\circ} \mathrm{C}$ for $15 \mathrm{~min}, 1 \mathrm{U}$ of RNase $\mathrm{H}$ (Gibco BRL) was added to the reaction mixture, followed by incubation at $37^{\circ} \mathrm{C}$ for $10 \mathrm{~min}$ to remove the RNA.

Aliquots of the cDNA were diluted from $1: 1$ to $1: 100$ and then amplified in $50 \mu \mathrm{l}$ of a PCR reaction mixture which contained $20 \mathrm{pmol}$ primer sets, $1 \times \mathrm{PCR}$ buffer $(10 \times=$ $100 \mathrm{~mm}$ Tris- $\mathrm{HCl}, 15 \mathrm{~mm} \mathrm{MgCl}_{2}$ and $500 \mathrm{~mm} \mathrm{KCl,} \mathrm{pH} 8.3$ ) (Roche, Mannheim, Germany), 0.2 mm dNTP mix (Takara Shuzo, Otsu, Japan) and 1 U Taq DNA polymerase (Roche). Primers for osteocalcin (sense: 5'-GCGAATTCATGAGGACCCTCTCTCTGCTC-3', antisense: 5'-GCGAATTCTAGATGCGYTTGTAGGCG-3') and bone sialoprotein (BSP) (sense: 5'-GCGAATTCTGAACGGGTTTCAGCAGAC-3', antisense: 5'-GCGAATTCTGGTGGTAGTAATAATCCT-3') were prepared based on published DNA sequences (GenBank accession numbers X04142 and S78239, respectively). Primers for BMP-2 (sense: 5'-CCGACGCTTCTTCTTCAAT-3', antisense: 5' -GCCACTTCCACCACAAACC-3'), BMP-4 (sense: 5'-GCCTGGACACCTCATCACA-3', antisense: 5'-TGCTTGGGACTACGCTTGG-3'), BMP-6 (sense: 5'-GCGAATTCACATGGGACTCCAGCTGAGT-3', antisense: 5'-GCGAATTCTCCACAAGCTCTCACAACCA-3') and TGF- $\beta 1$ (sense: $5^{\prime}$-GGCTTTCGCTTCAGTGCTCA-3', antisense: $5^{\prime}$-CGGGTTGTGTTGGTTGTAGA-3') were prepared based on published DNA sequences (GenBank accession numbers L20678, Z22607, X80992 and X52498, respectively). Primers for actin were prepared based on a previously described sequence. ${ }^{16)}$ Amplifications were performed in GeneAmp PCR system 9600 (Perkin Elmer, Norwalk, CT, U.S.A.). DNA amplification included an initial denaturation at $94{ }^{\circ} \mathrm{C}$ for $2 \mathrm{~min}$, followed by 21 (actin), 27 (ostocalcin and BMP-4), 30 (BSP, BMP-2 and TGF- $\beta 1$ ) or 35 (BMP-6) cycles of denaturation at $94^{\circ} \mathrm{C}$ for $1 \mathrm{~min}$, annealing at $55^{\circ} \mathrm{C}$ (BMP-6), $57^{\circ} \mathrm{C}$ (BMP-2, -4 and TGF- $\beta 1$ ) or $60^{\circ} \mathrm{C}$ (osteocalcin and actin) for $1 \mathrm{~min}$, and extension at $72^{\circ} \mathrm{C}$ for $1 \mathrm{~min}$. The final cycle included $5 \mathrm{~min}$ for extension. The PCR products were analyzed by electrophoresis in $1 \%$ agarose gels stained with ethidium bromide. The $100 \mathrm{bp}$ DNA Ladder (Takara Shuzo) was used as a molecular weight marker.

Statistical Analysis Values are represented as mean \pm S.D. The analysis was conducted with SPSS software (SPSS Inc., Chicago, IL, U.S.A.). Statistical comparison among the groups was performed with one way analysis of variance (ANOVA) followed by Dunnett $t$-test. A probability below $5 \%$ was considered statistically significant.

\section{RESULTS}

Differential Osteogenic Responsiveness of Fractionated FRC Cells to Dex Fractionated FRC cells were first evaluated for ALP activity on day 7 and calcium deposition on day 14 , since ALP is an early marker and calcium deposition a late marker of osteogenesis. In both assays, cells from fractions $1-3$ showed the greater activities than those from fractions 4 and 5 in response to Dex (A and B in Fig. 1). In contrast, activities of cells from fraction 5 were depressed when treated with Dex.
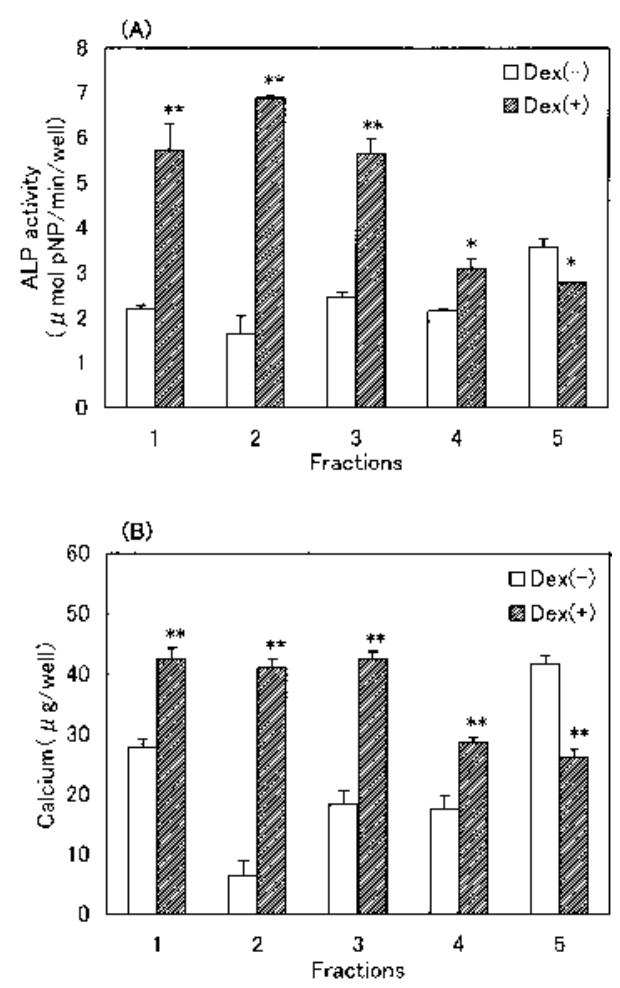

Fig. 1. Osteogenic Potential of Fractionated FRC Cells

FRC were enzymatically digested to produce fractionated populations of cells, as detailed in Materials and Methods. Cells released after each of five successive 20-min digestions were collected separately, and cultured in the presence or absence of Dex individually. ALP activity (A) and calcium content (B) were measured on days 7 and 14, respectively. Each measurement is the mean of triplicate cultures. Standard deviation (S.D.) of the mean is shown by vertical bars. Statistical significance compared to Dex $(-), * p<0.05, * * p<0.01$. 

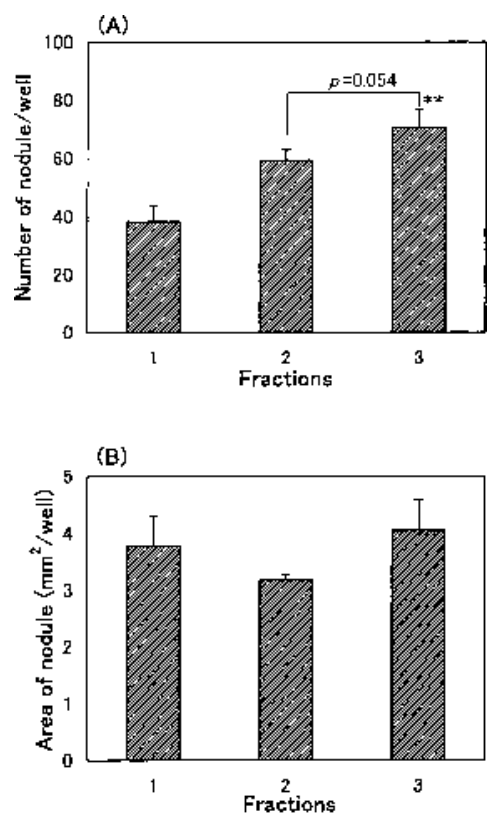

Fig. 2. Bone Nodule Formation in the Cultures of the First to Third Fractions of FRC Cells

Bone nodules in the Dex-treated cultures were subjected to von Kossa staining on day 14 and measured for nodule number (A) and total area (B) by an Image Analyzer. Each measurement is the mean of triplicate cultures. Standard deviation (S.D.) of the mean is shown by vertical bars. Statistical significance compared to fraction 1 , $* * p<0.01$.

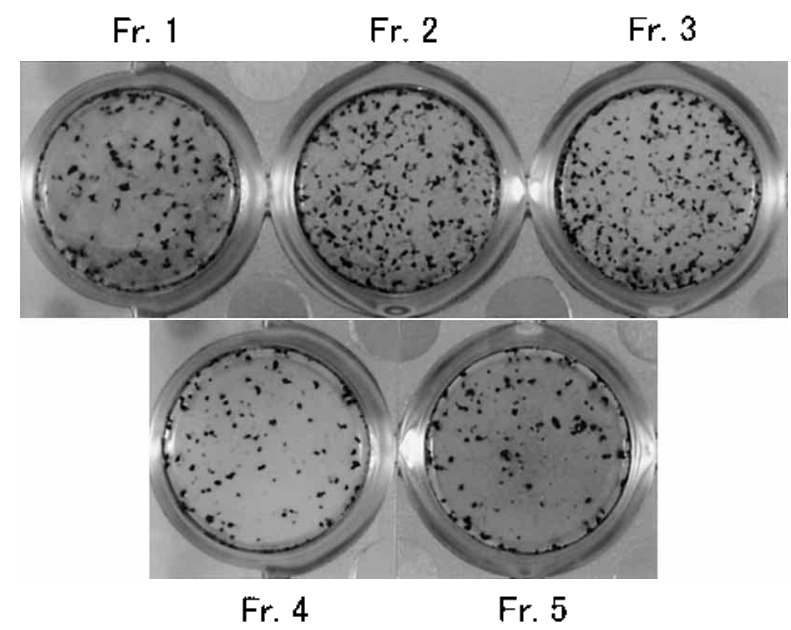

Fig. 3. Photographs of 14-Day Bone Nodules in the Dex-Treated Cultures of Each Fraction (Fr.) of FRC Cells

On day 14, the cultures were fixed with neutral buffered formalin and stained to visualize by the method of von Kossa. Magnification, $\times 2$.

Next, we assessed Dex-stimulated bone nodule formation in cultures of cells from fractions $1-3$. As shown in Fig. 2, the number of mineralized nodules was the greatest in cultures of fraction 3 and the fewer in that of faction 1 on day 14. However, total nodule area of each fraction was almost the same in all three fractions, and corresponded with calcium content (Fig. 1B). This would indicate that nodule size must be smallest in culture of fraction 3 and largest in fraction 1 (Fig. 2), which was confirmed by observations following after Von Kossa staining (Fig. 3).

These results revealed that fraction 3 derived from enzymatic digestion of FRC contains a large number of Dex-re-

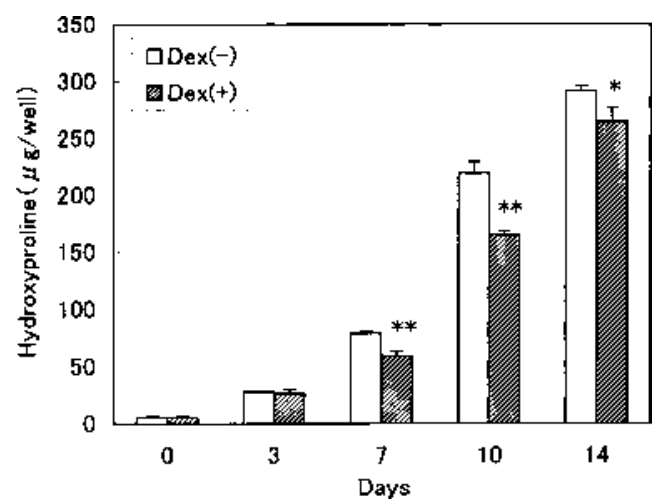

Fig. 4. Time Courses of Hydroxyproline Content during Osteoblastic Differentiation of the Third Fraction of FRC Cells

Hydroxyproline content in the cultures was measured for estimation of total collagen production by the method described in Materials and Methods. Each measurement is the mean of triplicate cultures. Standard deviation (S.D.) of the mean is shown by vertical bars. Statistical significance compared to Dex $(-), * p<0.05, * * p<0.01$.

Table 1. Time-Dependent Accumulation of Collagen Cross-Links in the Cultures of the Third Fraction of Fetal Rat Calvaria Cells

\begin{tabular}{|c|c|c|c|c|}
\hline \multirow{2}{*}{ Days } & \multirow{2}{*}{ Dex } & \multicolumn{2}{|c|}{ Collagen cross-links } & \multirow{2}{*}{$\begin{array}{l}\text { Ca contents } \\
(\mu \mathrm{g} / \text { well })\end{array}$} \\
\hline & & $\begin{array}{l}\text { Pyr (ng)/ } \\
\text { Hyd (ng) }\end{array}$ & $\begin{array}{l}\text { Dpy (ng)/ } \\
\text { Hyd (ng) }\end{array}$ & \\
\hline \multirow[t]{2}{*}{7} & - & ND & ND & ND \\
\hline & + & ND & ND & ND \\
\hline \multirow[t]{2}{*}{10} & - & $53.5 \pm 46.5$ & ND & NT \\
\hline & + & $196 \pm 55.3^{*}$ & ND & NT \\
\hline \multirow[t]{2}{*}{14} & - & $117 \pm 17.4$ & ND & $18.3 \pm 2.3$ \\
\hline & + & $227 \pm 49.7^{*}$ & $36.0 \pm 62.4$ & $42.4 \pm 1.3 * *$ \\
\hline \multirow[t]{2}{*}{21} & - & $166 \pm 27.3$ & $118 \pm 14.8$ & $51.7 \pm 2.5$ \\
\hline & + & $421 \pm 28.7 * *$ & $243 \pm 17.2 * *$ & $76.9 \pm 2.0 * *$ \\
\hline
\end{tabular}

Each value represents the mean \pm S.D. of triplicate cultures. Dex, Dexamethasone Pyr, pyridinoline; Dpy, deoxypyridinoline; Hyd, hydroxyproline; ND, not detected; NT, not tested. $* p<0.05$ and $* * p<0.01$ compared with the control (no treatment with Dex)

sponsive osteoprogenitor cells. Therefore, the cells from fraction 3 were cultured and analyzed for the following bone formation markers.

Production of Hydroxyproline and Collagen CrossLinks during Osteoblastic Differentiation We measured hydroxyproline content as an index of collagen production, and Pyr and Dpy as cross-links of mature collagens in culture of fraction 3 of FRC cells. Hydroxyproline content was increased with advancing time in culture as presented in Fig. 4. A marked increase in hydroxyproline was evident from days 7 to 10 , and its content reached maximum on day 14. The hydroxyproline content of Dex-treated cultures was significantly smaller than that of the control throughout the experiment. The amounts of collagen cross-links were also progressively elevated during the culture period (Table 1). The Pyr was detected as early as on day 10 and showed about ten-fold increase in the control on day 21. The Pyr content was about two- to three-fold larger in Dex-treated cultures than that in the control at any days examined. The effect of Dex stimulation was also prominent in Dpy formation; the Dpy was detected only in the cultures treated with Dex on day 14 and its content increased rapidly on day 21 . The appearance and accumulation of collagen cross-links is consistent with an onset of bone nodule formation and calcium deposition (Figs. 2, 3 

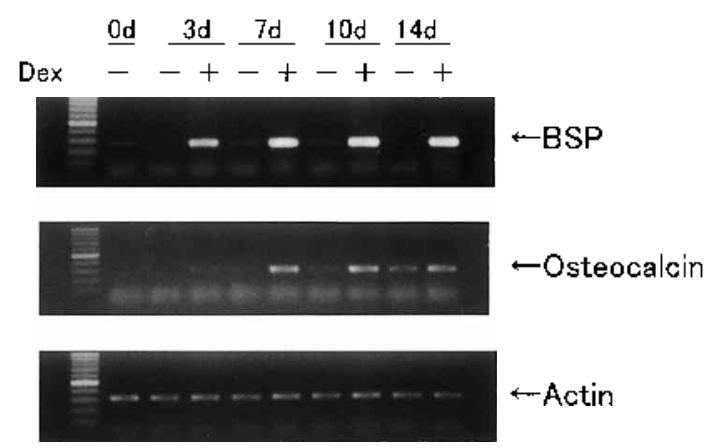

Fig. 5. RT-PCR Analyses for mRNA Expression of Non-collagenous Bone Matrix Proteins in Cultures of the Third Fraction of FRC Cells

RNA was extracted on days $0,3,7,10$, and 14 . Separate PCRs were performed for BSP ( $272 \mathrm{bp})$, osteocalcin $(301 \mathrm{bp})$ and actin $(313 \mathrm{bp})$. Reaction products were visualized on ethidium bromide-stained agarose gels. The first lane on the left represents molecular weight markers of the $100 \mathrm{bp}$ DNA Ladder.

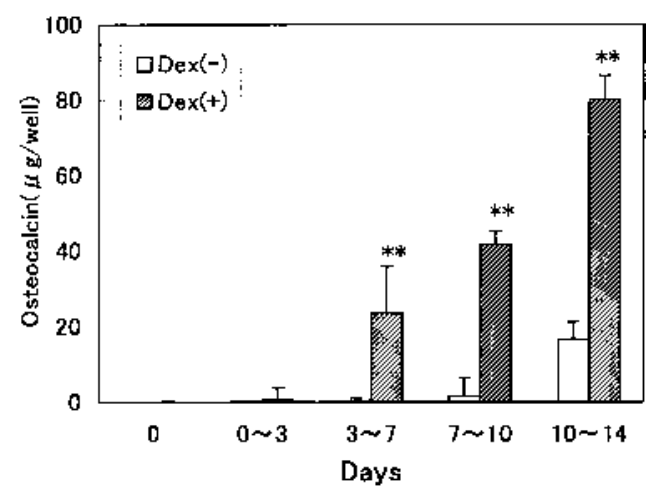

Fig. 6. Time Courses of Osteocalcin Secretion from the Third Fraction of FRC Cells

The culture media were harvested when they were freshly changed on days $0,3,7$, 10 , and 14 . The amount of osteocalcin secreted into the culture media during this period was determined by enzyme immunoassay. Statistical significance compared to Dex $(-), * * p<0.01$.

\section{and Table 1).}

Expression of Non-Collagenous Matrix Proteins during Osteoblastic Differentiation The mRNA expression of BSP and osteocalcin was investigated by RT-PCR in cultures of fracion 3 of FRC cells (Fig. 5). Dex stimulated the mRNA expression of BSP as early as on day 3 and its expression reached a plateau on day 7 . In comparison with Dex-treated cultures, the controls showed only a weak expression of BSP mRNA throughout the culture period. Osteocalcin mRNA was clearly detected on day 7 and its expression remained high on day 14. In contrast, the control showed a barely detectable osteocalcin mRNA expression only on day 14 .

Next, we examined protein production of osteocalcin into culture medium by ELISA (Fig. 6). In Dex-treated cultures, secreted osteocalcin was markedly accumulated from days 3 to 7 , whereas there was no detectable amount in controls. The amount of osteocalcin in Dex-treated cultures increased according to days in culture and almost doubled from days 10 to 14 , showing a good agreement with osteocalcin mRNA expression, bone nodule formation and calcium deposition. The control culture produced a trace amount of osteocalcin from days 7 to 10 , which was about a fifth the amount of osteocalcin generated in Dex-treated cultures from days 10 to 14.
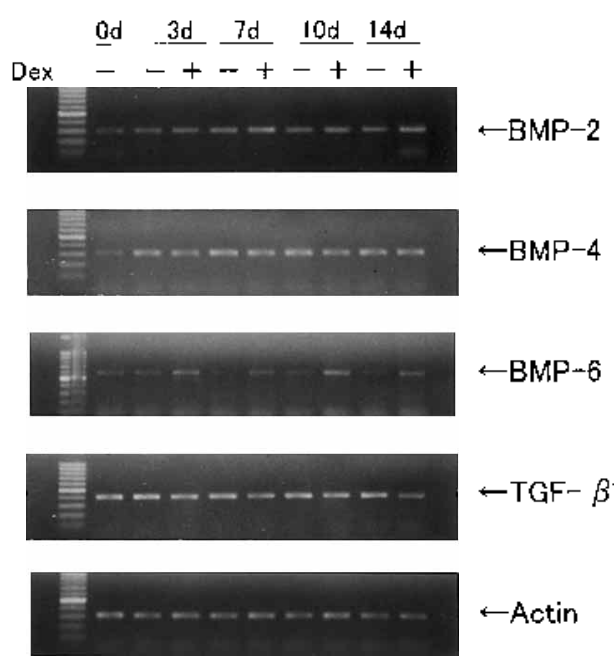

Fig. 7. RT-PCR Analyses for mRNA Expression of BMP and TGF- $\beta 1$ "Bone Formation-Inductive" Proteins in Cultures of the Third Fraction of FRC Cells

RNA was extracted on days $0,3,7,10$, and 14 . Separate PCRs were performed for BMP-2 (303 bp), -4 (312 bp), -6 (562 bp), TGF- $\beta 1$ (399 bp) and actin (313 bp). Reaction products were visualized as described for Fig. 5 .

Gene Expression of BMPs and TGF- $\beta 1$ during Osteoblastic Differentiation The time course of changes in mRNA expression of BMP-2, -4 and -6 , and TGF- $\beta 1$ was examined in the cultures of fraction 3 derived from FRC cells by semiquantitative RT-PCR method (Fig. 7). The expression of BMP-2, -4 and TGF- $\beta 1$ mRNA was detected on day 0 and their levels were not changed throughout the culture period. In contrast, expression of BMP- 6 mRNA was increased in Dex-treated cultures on days 3 and 10. In the control, BMP-6 mRNA decreased to a barely detectable level after day 7.

\section{DISCUSSION}

Timed and sequential enzymatic digestions were used to obtain various bone cell populations from FRC. Various methodologies have been applied for collecting osteoprogenitor cells from rat calvariae. ${ }^{6,9,18-20)}$ In these experiments, fractions of cells were used in combination and not fully characterized for osteoblast phenotype. Different preparations of calvaria cells obtained from different ages and strains of rats caused different results in each of these experiments. In this study, we first determined which fraction of cells was rich in osteoprogenitor cells in order to characterize the expression of the osteoblastic phenotype. Osteoprogenitor cells respond to Dex with a great sensitivity, resulting in enhanced expression of bone formation markers. ${ }^{6,11)}$ The first to third fraction of FRC cells responded to Dex well in assays of ALP activity and calcium deposition (Fig. 1). These data indicated that these were osteoprogenitor cells and immature osteoblasts localized in periosteum and bone surface, respectively. Among them, the third fraction of cells formed the greatest number of bone nodules, indicating that this fraction contained the largest number of osteoprogenitor cells. Since a size of bone nodules formed in the culture of the first fraction of cells was the largest irrespective of being almost equal in total area of nodules between the three fractions, the first fraction was considered to contain the most 
proliferative osteoprogenitor cells. On the other hand, the fourth and fifth fraction of cells responded to Dex poorly. Notably, the responsiveness of the fifth fraction of cells was inhibited by Dex treatment. It was unlikely that enzymatic digestion selectively impaired bone-formation activities of fractions 4 and 5 of cells, because they showed high cell viability (96-98\%) after the sequential digestions (data not shown) and equipotent ALP activities to cells from fractions 1 to 3 in the control cultures (no treatment with Dex) (A in Fig. 1). In addition, control cultures of fraction 5 exhibited higher ALP activity and calcium deposition than those of fractions 1 to 3 (A and B in Fig. 1). Even when a different lot of collagenase (Sigma) was used, bone-formation activities of fractionated FRC cells were not changed (data not shown). The level of glucocorticoid receptor expression in osteocytes is considerably lower than osteoblasts. ${ }^{21)}$ It seemed likely that fractions 4 and 5 contained many osteocytes, which were embedded in bone matrix within the calvaria. The analyses for Dex-responsive osteogenic activities of each fraction of cells derived from sequential enzymatic digestion of FRC offered the most suitable osteoprogenitor cell population for examination of osteoblast differentiation.

Osteoblasts synthesize and secrete collagen molecules, which are predominantly stabilized by cross-links from hydroxyallysine route, such as Pyr and Dpy. ${ }^{22,23)}$ While time-dependent increase in collagen production was less in Dextreated cultures compared with that of controls, the crosslinking of collagens was more prominent in Dex-treated cultures than that in controls. Dpy cross-links, which are reported to be more specific to bone collagen than Pyr, ${ }^{22)}$ were detected only in Dex-treated cultures as early as on day 14 and rapidly increased in the amount during the mineralizing phase of Dex-treated cultures (Table 1). These data strongly suggested that collagen maturation manifested by cross-link formation contributed to osteoblast differentiation of fractionated FRC cells, and collagen cross-linking was a more reliable late marker of osteoblast phenotype than collagen production. Time-dependent increase in collagen cross-links was found in the cultures of a mouse ostoblastic cell line and embryonic chick carvaria cells. ${ }^{24,25)}$ Recently, fully differentiated bone marrow stromal cells treated with Dex, but not normal skin fibroblasts, exhibited a significantly elevated level of a lysyl hydroxylase mRNA, which was closely associated with the increase in lysyl hydroxylation and crosslinking of type I collagen molecule, and matrix mineralization during osteoblastic differentiation in vitro. ${ }^{26)}$ It was also likely that enhanced activity of this enzyme induced a marked formation of collagen cross-links, leading to promotion of matrix mineralization in cultures of fractionated FRC cells. This is an interesting subject for further investigation.

Noncollagenous matrix proteins also contribute to osteoblast differentiation and bone formation. BSP is an ArgAsp-Gly (RGD)-containing adhesive matrix proteins of bone that is expressed by osteoblast. ${ }^{27)}$ The mRNA expression of BSP was detected only in the Dex-treated cultures from day 3 , indicating that this protein was the earliest differentiation marker of osteoblasts in this model system. Osteocalcin mRNA was expressed from day 7 and coincided with an onset of active secretion to culture media in Dex-treated cultures. A large amount of osteocalcin was found in Dextreated cultures from days 10 to 14 when many calcified bone nodules appeared. Osteocalcin expression is associated with mineralization phenomenon of osteoblast cultures and is a regarded as a terminal marker of culture differentiation. ${ }^{4)}$ The present observation that osteocalcin expression was observed preferentially at the stage of culture mineralization is consistent with this interpretation.

BMPs and TGF- $\beta 1$ are thought to play important roles in bone formation both in vivo and in vitro. ${ }^{28)}$ Between them, a change in mRNA expression was observed only in BMP-6, which became elevated in the cultures treated with Dex on days 3 and 10. Moreover, the expression of BMP- 6 mRNA was constantly higher in Dex-treated cultures than in the control throughout the culture period. Harris et al. reported that expression of BMP-2, -4 and -6 mRNA were all elevated in cultures of FRC cells, coincident with the formation of mineralized bone nodules on days 10 to 12 and then decreased by day $20 .{ }^{19)}$ Discrepancy between their results and ours may be ascribed to the preparation of calvaria cells and age of rat fetus. They used cells pooled from third to fifth fraction of every 20 min digestion of 19-d-old FRC. Boden et al. showed that glucocorticoid-induced differentiation of rat calvaria cells was mediated by BMP-6, not by BMP-2, -4, -5, -7 and TGF- $\beta 1{ }^{29)}$ Our results are well consistent with Boden et al., although peak BMP-6 mRNA level was observed as early as $12 \mathrm{~h}$ after Dex treatment in their culture system. Again, different preparations of osteoprogenitor cells could cause different results on peak time of BMP-6 expression. In preliminary experiments, we checked time-course changes in mRNA expression of BMP receptors by RT-PCR method. There was no obvious change in the expression of BMP receptors type IA and IB. Therefore, we speculate that BMP-6 is a crucial regulator in osteoblast differentiation and its expression is one of predictive bone formation markers in cultures of FRC cells.

In conclusion, our observations suggest that the culture system we present here using osteoprogenitor-enriched population of cells isolated from FRC is a suitable model for in vitro bone formation. This assay system allows us to evaluate the osteogenic activity of peptide growth factors, hormones and chemically synthesized compounds.

Acknowledgements We are grateful to Dr. James E. Dennis, Skeletal Research Center, Case Western Reserve University, Cleveland, Ohio, U.S.A., for reviewing this manuscript.

\section{REFERENCES}

1) Tenenbaum H. C., "The Osteoblast and Osteocyte," Vol. 1, ed. by Hall B. K., The Telford Press, Caldwell, 1990, pp. 41-69.

2) Caplan A. I., Clin. Plastic Surg., 21, 429-435 (1994).

3) Nijweide P. I., "The Osteoblast and Osteocyte," Vol. 1, ed. by Hall B. K., The Telford Press, Caldwell, 1990, pp. 303-326.

4) Majeska R. J., "Principles of Bone Biology," ed. by Bilezikian J. P., Raisz L. G., Rodan G. A., Academic Press, San Diego, 1996, pp. $1229-1237$.

5) Aronow M. A., Cerstenfeld L. C., Owen T. A., Tassinari M. S., Stein G. S., Lian J. B., J. Cell. Physiol., 143, 213-221 (1990).

6) Bellows C. G., Heersche J. N. M., Aubin J. E., Dev. Biol., 140, $132-$ 138 (1990).

7) Bellows C. G., Aubin J. E., Heersche J. N. M., Antosz M. E., Calcif. Tissue Int., 38, 143-154 (1986).

8) Wada Y., Kataoka H., Yokose S., Ishizuya T., Miyazono K., Gao Y.-H., Shibasaki Y., Yamaguchi A., Bone, 22, 479—485 (1998). 
9) Owen T. A., Aronow M., Shalhoub V., Barone L. M., Wilming L., Tassinari M. S., Kennedy M. B., Pockwinse S., Lian J. B., Stein G. S., J. Cell. Physiol., 143, 420-430 (1990).

10) Victoria S., Conlon D., Tassinari M., Partridge N., Stein G. S., Lian J. B., J. Cell. Biochem., 50, 425-440 (1992).

11) Bellows C. G., Ciaccia A., Heersche J. N. M., Bone, 23, 119-125 (1998).

12) Dennis J. E., Caplan A. I., J. Cell. Physiol., 167, 523-538 (1996).

13) Bellows C. G., Aubin J. E., Dev. Biol., 133, 8-13 (1989).

14) Hanada K., Dennis J. E., Caplan A. I., J. Bone Miner. Res., 12, $1606-$ 1614 (1997).

15) Kivirikko K. I., Laitinen O., Prockop D. J., Anal. Biochem., 19, 249255 (1967).

16) Black D., Duncan A., Robins S. P., Anal. Biochem., 169, 197-203 (1988).

17) Ide H., Yoshida T., Matsumoto N., Aoki K., Osada Y., Sugimura T., Terada M., Cancer Res., 57, 5022-5027 (1997).

18) Mccarthy T. L., Centrella M., Canalis E., J. Bone Miner. Res., 3, 401408 (1988).

19) Harris S. E., Sabatini M., Harris M. A., Feng J. Q., Wozney J., Mundy G. R., J. Bone Miner. Res., 9, 389-394 (1994).
20) Ishizuya T., Yokose S., Hori M., Noda T., Suda T., Yoshiki S., Yamaguchi A., Clin. Invest., 99, 2961-2970 (1997).

21) Beavan S., Horner A., Bord S., Ireland D., Compston J., J. Bone Miner. Res., 16, 1496-1504 (2001).

22) Eyre D. R., "Principles of Bone Biology," ed. by Bilezikian J. P., Raisz L. G., Rodan G. A., Academic Press, San Diego, 1996, pp. 143-153.

23) Yamaguchi M., Katz E. P., Connec. Tissue Res., 29, 81—98 (1993).

24) Kuboki Y., Kudo A., Mizuno M., Kawamura M., Calcif. Tissue Int., 50, 473-480 (1992).

25) Gerstenfeld L. C., Riva A., Hodgens K., Eyre D. R., Landis W. J., J. Bone Miner. Res., 8, 1031-1043 (1993).

26) Uzawa K., Grzesik W. J., Nishiura T., Kuznetsov S. A., Robey P. G., Brenner D. A., Yamauchi M., J. Bone Miner. Res., 14, 1272-1280 (1999).

27) Heinegard D., Lorenzo P., Saxne T., "Dynamics of Bone and Cartilage Metabolism," ed. by Seibel M. J., Robins S. P., Bilezikian J. P., Academic Press, Orland, 1999, pp. 59-69.

28) Ducy P., Karsenty G., Kidney Int., 57, 2207-2214 (2000).

29) Boden S. D., Hair G., Titus L., Rachine M., Mccuaig K., Wozney J. M., Nanes M. S., Endocrinology, 138, 2820-2828 (1997). 